\title{
Water Quality Assessment of Some Selected Well Waters of Sabo Yeregi in Katcha Local Government of Niger State
}

\author{
Shaba Elijah Yanda ${ }^{1, ~ *, ~ N d a m i t s o ~ M u h a m m e d ~ M u h a m m e d ~}{ }^{1}$, Mathew John Tsado ${ }^{1}$, \\ Abdullahi Zalihat ${ }^{1}$, Tsado Amos Ndarubu ${ }^{2}$, Gabriel Ilemona ${ }^{1}$ \\ ${ }^{1}$ Department of Chemistry, Federal University of Technology, Minna Niger State, Nigeria \\ ${ }^{2}$ Department of Basic and Applied Sciences, Niger State Polytechnic, Zungeru Niger State, Nigeria
}

Email address:

elijah.shaba@futminna.edu.ng (S. E. Yanda),johntsadom@yahoo.com (M. J. Tsado)

To cite this article:

Shaba Elijah Yanda, Ndamitso Muhammed Muhammed, Mathew John Tsado, Abdullahi Zalihat, Tsado Amos Ndarubu, Gabriel Ilemona. Water Quality Assessment of Some Selected Well Waters of Sabo Yeregi in Katcha Local Government of Niger State. American Journal of Applied Chemistry. Vol. 3, No. 5, 2015, pp. 174-178. doi: 10.11648/j.ajac.20150305.14

\begin{abstract}
Water quality assessment of some seleted well waters of Sabo Yeregi in Katcha Local Government Area of Niger state was carried out using standard analytical methods. Water is a valued natural resource for survival of all living things; the importance of assessing the quality of this valued resource cannot be overemphasized. In this study, the physical, chemical and microbial values were analyzed from six well water samples collected from Sabo Yeregi, Katcha Local Government Area of Niger State using standard methods. The $\mathrm{pH}$ ranges $6.30 \pm 0.04$ to $7.15 \pm 0.07$. Nitrite ranged from $0.03 \pm 0.02$ to $0.11 \pm$ $0.01 \mathrm{mg} / \mathrm{L}$. Well $1(85.45 \pm 0.64)$ has the highest total dissolved solids (TDS). Iron recorded $0.24 \pm 0.02 \mathrm{mg} / \mathrm{L}$ as the highest and $0.07 \pm 0.00 \mathrm{mg} / \mathrm{L}$ as the lowest in well 5 and 6 respectively. The hardness for well 1, 2, 3, 4, 5 and 6 were $113.50 \pm 0.71,38.00$ $\pm 1.42,63.00 \pm 0.00,27.50 \pm 0.71,31.50 \pm 0.71$ and $38.00 \pm 1.42 \mathrm{mg} / \mathrm{L}$ respectively. The sulphate concentration is $64.68 \pm 0.06$, $89.22 \pm 0.09,92.74 \pm 0.0929 .01 \pm 0.09,102.27 \pm 0.41$, and $77.25 \pm 0.11 \mathrm{mg} / \mathrm{L}$ for well $1,2,3,4,5$ and 6 respectively. The highest temperature recorded was $29.06 \pm 0.090 \mathrm{C}$ and the lowest was $27.92 \pm 0.02$ well 5 and 3 respectively. The turbidity was $4.42 \pm 0.06,0.50 \pm 0.04,0.36 \pm 0.08,2.06 \pm 0.06,2.37 \pm 0.21$ and $2.47 \pm 0.05 \mathrm{NTU}$ for well $1,2,3,4,5$, and 6 . All the parameters were within the NSDWQ and WHO standard except pH in well 1, 2, 6, hardness, nitrate in (well 4) and manganese (in well 3). All the samples contain coliform with the exception of well 5 but there is no present of E.coli in any of the sample.
\end{abstract}

Keywords: Physical, Chemical, Microbial, Sabo Yeregi, Katcha

\section{Introduction}

Recent research carried-out by Yisa et al., [1] reported that there has been increment in the interest for fresh water because of expansion in development of populace and in addition the rate of industrialization in the most recent couple of decades. The extensive scale industrial development has brought about genuine concerns with respect to the helplessness of groundwater sullying because of release of waste materials. Waste materials close manufacturing plants are subjected to response with permeating precipitation water and along these lines achieve the aquifer framework and in that capacity corrupt the groundwater quality. Mining is one of the occupations of people leaving in Sabo Yeregi in Katcha local government of Niger state, so there is every tendency that the water in this community may be contaminated. Therefore it is become very necessary to determine the levels of the contaminants in the water due to this activity to ascertain the safety of the local people whose lives totally depend on this water.

In the last two decades, there has been a tremendous increase in the demand for water due to rapid increase in population and in industrialization [2]. This demand for water has led to the use of groundwater, the desire for underground water is not only for its wide spread occurrence and availability but also for its constituent good quality which makes it ideal for drinking [3]. Water quality refers to the physical, chemical and biological attributes of water [4]. It is the measure of the condition of water in relation to the requirements of one or more biotic species and any human need or purpose [5]. Safe drinking water is fundamental to people and different types of life. Access to safe drinking 
water has enhanced in the course of the most recent decades in all aspects of the world, however more or less one billion individuals still need access to great drinking water [6]. Direct pollution of surface waters with metals in releases from mining, refining and mechanical assembling is a longstanding phenomenon. On the other hand, the outflow of airborne metallic toxins has now come to such extents that long-extend environmental transport results to pollution in the region of industrialized locales, as well as in more remote ranges. Similarly, moisture in the atmosphere combines with some gases produced when fossil fuels are burnt and causes acidification of surface waters, falling as acid rain, especially lakes [7].

Groundwater has long been considered as one of the purest types of water accessible in nature and takes care of the general requests for provincial and semi-rural people [8]. Individuals around the globe have utilized groundwater as a wellspring of drinking water and even today more than a large portion of the world's populace relies on upon groundwater for survival [9].

\section{Materials and Method}

\subsection{Sample Collection}

Six well samples were randomly collected in Sabo Yeregi community of Katcha Local Government Area of Niger State. The samples were taken in polyethylene bottles. These bottles were washed with $10 \% \mathrm{HNO}_{3}$ and were rinsed thoroughly. The temperature and the $\mathrm{pH}$ of the samples were taken on site using thermometer and $\mathrm{pH}$ meter respectively. The bottles were clearly labeled with site location and were taken to laboratory for analysis [10].

\subsection{Conductivity Determination}

The conductivities of the samples were determined using Conductivity Meter (JENWAY MODEL 4520). The probe of the conductivity meter was submerged in the test sample contained in plastic beaker to avoid electromagnetic interferences. This was followed by the measurement of the sample after the stability symbol on the top left the Control Display appears. The COND mode was selected with the READ button ( JENWAY MODEL manual). The measurements were then taken.

Turbidity and Total Alkalinity was determined was analyzed through the method as described by Dawodu and Ipaiyeda, [7]

\subsection{Total Hardness Determination (Titrimetric Method) and Chloride Ion}

Total Hardness Determination (Titrimetric Method) and Chloride Ion was calculated as described by Trivedy and Goel, [11].

\subsection{Temperature Determination}

The temperature measurements were carried out on site using Hannah HI935005 microprocessor- based thermometer on the degree centigrade $\left(0^{0} \mathrm{C}\right)$ scale.

\subsection{Determination of Nitrite, Nitrate, Sulphate, Phosphate, Manganese, Iron, Zinc by Colorimetric Method}

- The stored programmed number was entered from the colorimeter

- $\mathrm{Mg} / \mathrm{l}$ and zero icons were displayed by pressing the ENTER button

- $10 \mathrm{ml}$ of the sample was measured into one sample cell and the other sample cell was filled $\left(10 \mathrm{~cm}^{3}\right)$ with distilled water as the blank

- The appropriate reagent was added to the sample cell containing the water sample and was thoroughly shaking to dissolve the reagent

- TIMER button was pressed to begin a reaction period

- A cell containing the sample was placed into the sample holder and $0.00 \mathrm{mg} / \mathrm{l}$ was displayed by pressing ZERO button and the blank was removed from the cell holder

- The sample cell containing the water sample was then placed into the sample cell holder and the reading was taken by pressing READ button (HACH 895 DR Colorimeter Manual)

\subsection{Microbial Analysis}

\subsubsection{Media Preparation}

$26 \mathrm{~g}$ of lactose broth was measured into 1litre of distilled water and was mixed thoroughly using a magnetic stirrer, and also $10 \mathrm{~cm}^{3}$ of the solution was measured into McCartney bottles containing Durham's tube ( 5 bottles represented one sample). The bottles were arranged inside an autoclave and were sterilize for $15 \mathrm{~min}$ at $120{ }^{\circ} \mathrm{C}$ to destroy the microorganisms present. After sterilization, the lactose broths were then cooled [12].

\subsubsection{Presumptive Test}

$10 \mathrm{~cm}^{3}$ of thesample was poured into the lactose broth solution (prepared media) and were then incubated for 24hours. After the 24hours, the bottles were checked for contamination which may appear in the form of cloudiness in the samples or bubbles trapped by the Durham tubes [12].

\subsubsection{Confirmatory Test}

$37.5 \mathrm{~g}$ of EMB was weighed into 1litre of distilled water and was stirred using magnetic stirrer then was sterilized using the autoclave at $120^{\circ} \mathrm{c}$ for 15 minutes and after and was brought out and allowed to cool. The Petri dish was sterilized and $20 \mathrm{~cm}^{3}$ of EMB was dispensed into each dish. The contaminated solution is streaked using an already sterilized wire loop on the EMB plate and were incubated for another 24hours [13].

\subsection{Statistical Analysis}

All determinations were performed in triplicates. The results obtained were subjected to statistical analysis using means and standard deviations. 


\section{Result and Discussion}

\subsection{Result}

Table 1. Result of the Physico-Chemical Analysis of the 6 Samples.

\begin{tabular}{|c|c|c|c|c|c|c|c|c|}
\hline PARAMETER & Well 1 & Well 2 & Well 3 & Well 4 & Well 5 & Well 6 & NSDWQ & WHO \\
\hline Temperature $\left({ }^{0} \mathrm{C}\right)$ & $28.89 \pm 0.01$ & $28.63 \pm 0.04$ & $27.92 \pm 0.02$ & $28.00 \pm 0.14$ & $29.06 \pm 0.09$ & $28.35 \pm 0.07$ & AMBIENT & 30.00 \\
\hline $\mathrm{pH}$ & $6.41 \pm 0.08$ & $6.30 \pm 0.04$ & $6.53 \pm 0.04$ & $7.15 \pm 0.07$ & $6.53 \pm 0.04$ & $6.43 \pm 0.04$ & 6.58 .50 & $6.50-8.50$ \\
\hline Conductivity $(\mu \mathrm{S} / \mathrm{cm})$ & $132.81 \pm 0.01$ & $89.63 \pm 0.04$ & $91.68 \pm 0.04$ & $68.95 \pm 0.07$ & $105.65 \pm 0.35$ & $112.55 \pm 0.49$ & 1000.00 & 1000.00 \\
\hline Turbidity (NTU) & $4.42 \pm 0.04$ & $0.50 \pm 0.04$ & $0.36 \pm 0.08$ & $2.06 \pm 0.06$ & $2.37 \pm 0.21$ & $2.47 \pm 0.05$ & 5.00 & 5.00 \\
\hline Colour (TCU) & $10.50 \pm 0.71$ & $0.00 \pm 0.00$ & $4.50 \pm 0.07$ & $1.00 \pm 0.00$ & $3.50 \pm 0.71$ & $6.00 \pm 0.00$ & 15.00 & 15.00 \\
\hline TDS $(\mathrm{Mg} / \mathrm{L})$ & $85.45 \pm 0.64$ & $36.10 \pm 0.14$ & $67.25 \pm 0.36$ & $44.05 \pm 0.07$ & $40.10 \pm 0.14$ & $69.30 \pm 0.43$ & 500.00 & 1000.00 \\
\hline Salinity $(\mathrm{Mg} / \mathrm{L})$ & $0.20 \pm 0.14$ & $0.79 \pm 0.01$ & $0.59 \pm 0.01$ & $0.30 \pm 0.01$ & $0.26 \pm 0.06$ & $0.13 \pm 0.04$ & 100.00 & 100.00 \\
\hline T. hardness $(\mathrm{Mg} / \mathrm{L})$ & $130.20 \pm 0.14$ & $48.50 \pm 0.71$ & $80.50 \pm 0.71$ & $41.00 \pm 1.42$ & $49.00 \pm 0.94$ & $48.50 \pm 0.71$ & 150.00 & 500.00 \\
\hline T. alkalinity $(\mathrm{Mg} / \mathrm{L})$ & $35.95 \pm 0.07$ & $32.20 \pm 0.28$ & $40.40 \pm 0.57$ & $45.30 \pm 0.43$ & $38.50 \pm 0.72$ & $35.35 \pm 0.50$ & 100.00 & 100.00 \\
\hline $\mathrm{Ca}^{2+}$ hardness $(\mathrm{Mg} / \mathrm{L})$ & $113.50 \pm 0.71$ & $38.00 \pm 1.42$ & $63.00 \pm 0.00$ & $27.50 \pm 0.71$ & $27.50 \pm 0.71$ & $38.00 \pm 1.42$ & 75.00 & 75.00 \\
\hline $\mathrm{Mg}^{2+}$ hardness $(\mathrm{Mg} / \mathrm{L})$ & $15.50 \pm 0.72$ & $9.25 \pm 0.35$ & $18.00 \pm 1.42$ & $12.75 \pm 1.06$ & $18.25 \pm 0.35$ & $10.50 \pm 0.72$ & 30.00 & 50.00 \\
\hline
\end{tabular}

NOTE: NSDWQ = Nigerian Standard for Drinking Water Quality; WHO = World Health Organization

Table 2. Result of the Inions Analysis of the 6 Samples.

\begin{tabular}{|c|c|c|c|c|c|c|c|c|}
\hline PARAMETERS & Well 1 & Well 2 & Well 3 & Well 4 & Well 4 & Well 6 & NSDWQ & WHO \\
\hline Chloride Ion $(\mathrm{Mg} / \mathrm{L})$ & $18.22 \pm 0.01$ & $50.79 \pm 0.05$ & $61.05 \pm 0.21$ & $94.08 \pm 0.25$ & $53.72 \pm 0.09$ & $69.80 \pm 0.28$ & 250.000 & 250.00 \\
\hline Phosphate Ion (Mg/L) & $5.16 \pm 0.08$ & $4.78 \pm 0.16$ & $2.13 \pm 0.05$ & $3.36 \pm 0.04$ & $6.25 \pm 0.08$ & $1.99 \pm 0.02$ & 6.50 & 6.50 \\
\hline Nitrate Ion $(\mathrm{Mg} / \mathrm{L})$ & $32.58 \pm 0.18$ & $21.15 \pm 0.35$ & $18.26 \pm 0.33$ & $50.80 \pm 0.43$ & $19.46 \pm 0.48$ & $34.05 \pm 0.06$ & 50.00 & 50.00 \\
\hline Sulphate Ion $(\mathrm{Mg} / \mathrm{L})$ & $64.68 \pm 0.06$ & $89.22 \pm 0.29$ & $92.74 \pm 0.04$ & $29.01 \pm 0.09$ & $102.27 \pm 0.41$ & $77.25 \pm 0.11$ & 100.00 & 400.00 \\
\hline
\end{tabular}

Table 3. Result of the Metal Analysis of the 6 Samples.

\begin{tabular}{|c|c|c|c|c|c|c|c|c|}
\hline PARAMETERS & Well 1 & Well 2 & Well 3 & Well 4 & Well 4 & Well 6 & NSDWQ & WHO \\
\hline Calcium (mg/L) & $63.10 \pm 0.17$ & $31.95 \pm 0.07$ & $56.27 \pm 0.08$ & $28.86 \pm 0.19$ & $30.65 \pm 0.77$ & $18.24 \pm 0.33$ & 50.00 & 50.00 \\
\hline Magnesium $(\mathrm{mg} / \mathrm{L})$ & $3.45 \pm 0.64$ & $2.18 \pm 0.02$ & $4.07 \pm 0.08$ & $2.53 \pm 0.81$ & $4.22 \pm 0.25$ & $2.71 \pm 0.04$ & 10.00 & 10.00 \\
\hline $\operatorname{Iron}(\mathrm{mg} / \mathrm{L})$ & $0.09 \pm 0.00$ & $0.16 \pm 0.01$ & $0.09 \pm 0.01$ & $0.14 \pm 0.00$ & $0.24 \pm 0.02$ & $0.07 \pm 0.00$ & 0.30 & 0.30 \\
\hline Manganese (mg/L) & $0.03 \pm 0.00$ & $0.01 \pm 0.00$ & $0.21 \pm 0.03$ & $0.03 \pm 0.00$ & 0.00 & $0.01 \pm 0.00$ & 0.20 & 0.20 \\
\hline
\end{tabular}

Table 4. Result of the Bacteriological Analysis of the 6 Samples.

\begin{tabular}{lllllllll}
\hline PARAMETERS & Well 1 & Well 2 & Well 3 & Well 4 & Well 5 & Well 6 & NSDWQ & WHO \\
\hline Coliforms & 1.001 & 4.00 & 2.00 & 5.00 & 0.00 & 4.00 & $0 / 100 \mathrm{ml}$ & $0 / 100 \mathrm{ml}$ \\
E. coli & - & - & - & - & - & - & $0 / 100 \mathrm{ml}$ & $0 / 100 \mathrm{ml}$ \\
\hline
\end{tabular}

\subsection{Discussion of Results}

The results of the Physico-Chemical analysis of the 6 samples well water is shown in table 1. The temperature recorded in this work ranged from 27.92 to $29.06 \pm 0.09^{\circ} \mathrm{C}$. The result is slightly lower than $30.83-31.7^{0} \mathrm{C}$ as reported by Olalekan et al., [14]. This values are within the WHO accepted value of $30.00^{\circ} \mathrm{C}$ for temperature of drinking water. This result disagrees with the work of Olatunji et al., [15] which reported $6.43 \pm 0.25$ as maximum and $6.32 \pm 0.26{ }^{\circ} \mathrm{C}$ as minimum. The variation in the temperature may be attributed to the difference in the depth, location and season of analysis. The deeper the well the colder the water [16]. The $\mathrm{pH}$ of the samples were $6.41 \pm 0.08,6.30 \pm 0.04,6.60 \pm 0.08,7.15 \pm 0.07,6.53 \pm 0.04$ and $6.43 \pm 0.04$ for Well 1, 2, 3, 4, 5 and 6 respectively. These values are similar to NSDWQ and WHO $\mathrm{pH}$ standard of between 6.50 to 8.50. An abnormal $\mathrm{pH}$ can lead to corrosion, and also has effect on mucous membrane as reported by Narasinha et al., [17]. This result is similar to those of Ajibare,
[18] and Olatunji et al., [15]. The highest electrical conductivity recorded was $132.81 \pm 0.01 \mu \mathrm{S} / \mathrm{cm}$ while the lowest value was $68.95 \pm 0.07 \mu \mathrm{S} / \mathrm{cm}$ in well 1 and 4 respectively. This result is higher than NSDWQ and WHO limit of $1000 \mu \mathrm{S} / \mathrm{cm}$ and $1250 \mu \mathrm{S} / \mathrm{cm}$ respectively.

The turbidity ranged from $0.36 \pm 0.08 \mathrm{NTU}$ (well 3 ) to 4.42 $\pm 0.04 \mathrm{NTU}$ (well 1), and the values fall within the NSDWQ and WHO turbidity limit of 5.0NTU. The range is not in correlation with the work of Yisa et al., [19]. This variation may be due to the difference in the level of algae, erosion into the water as well as the dissolved substance in the water. The turbidity above 5.0NTU is health threat because the contaminant like bacteria or virus can be attached the material that is responsible for the turbidity as reported by Higgins et al., [20].

The colour of the samples ranged from $0.00 \mathrm{TCU}$ (well 2) to $10.50 \pm 0.71 \mathrm{TCU}$ (well 1). Well 2 showed the best colour unit among others in relation to colour attribute of water because the smaller the colour unit the better the colour. Well 1 has the highest colour unit but still within the NSDWQ and WHO 
colour limit of 15TCU. The total dissolved solids (TDS) of the samples are $85.45 \pm 0.64,36.10 \pm 0.14,67.25 \pm 0.07,44.05 \pm$ $0.07,40.10 \pm 0.14$ and $69.30 \pm 0.04 \mathrm{mg} / \mathrm{L}$ respectively. The values fall within the NSDWQ and WHO limit of $500 \mathrm{mg} / \mathrm{L}$ and $1500 \mathrm{mg} / \mathrm{L}$ respectively. The values are similar to that of Tyagi et al., [8].

The salinity of the samples ranged from $0.13 \pm 0.04 \%$ (well 6) $-0.79 \pm 0.01 \%$ (well 2) and the values are suitable in comparison with the NSDWQ and WHO limit of $100 \%$. The values are not in correlation with the values obtained by Yisa et al., [19]. The highest value recorded for total hardness was $130.20 \pm 0.14 \mathrm{mg} / \mathrm{L}$ and the lowest value was $41.00 \pm 1.42$ $\mathrm{mg} / \mathrm{L}$ which are still within the NSDWQ and WHO standard of $150 \mathrm{mg} / \mathrm{L}$ and $500 \mathrm{mg} / \mathrm{L}$ respectively. According to Higgins et al., [20], individuals typically report aesthetic problem whenever the level of total hardness of water is $160 \mathrm{mg}$ $\mathrm{CaCO}_{3} / \mathrm{L}$ and above. From this, well 4 with low hardness are more aggressive than well 1 with higher value. The values of the hardness obtained were also similar to those in the work of Anshu et al., [21]. The total alkalinity of the samples was recorded to be $32.20 \pm 0.23 \mathrm{mg} / \mathrm{L}$ as the highest and $43.30 \pm$ $0.43 \mathrm{mg} / \mathrm{L}$ as the lowest which fall within the NSDWQ and WHO limit of $100 \mathrm{mg} / \mathrm{L}$. The result is not in correlation with Rathose et al., [22]. This may be due to the differences in $\mathrm{pH}$ values since the higher the $\mathrm{pH}$ value the higher the alkalinity of the water as reported by Wilkies University [16].

The calcium hardness of the sample was $113.50 \pm 0.71$, $38.00 \pm 1.42,63.00 \pm 0.00,27.50 \pm 0.71,31.50 \pm 0.71$ and38.00 $\pm 1.42 \mathrm{mg} / \mathrm{L}$ for well $1,2,3,4,5$, and 6 respectively. Well 1 exceeds the WHO limit of $75 \mathrm{mg} / \mathrm{L}$. This high level of calcium hardness decreases lather forming capacity of soap and increases the formation of scale in water heater as reported by Olasehinde, [23]. The similarities in the values were compared with that of Hudault et al., [12].This may be due to the type of the geological rock present in the environment

The samples have magnesium hardness ranging from $9.25 \pm$ $0.35 \mathrm{mg} / \mathrm{L}$ (well 2) $-18.25 \pm 0.35 \mathrm{mg} / \mathrm{L}$ (well 5) and the values are within the NSDWQ and WHO limit of $30 \mathrm{mg} / \mathrm{L}$ and $50 \mathrm{mg} / \mathrm{L}$ respectively. The result of calcium ion is $63.10 \pm 0.17$, $31.95 \pm 0.07,56.27 \pm 0.08,28.86 \pm 0.10,30.65 \pm 0.07$ and $18.24 \pm 0.33 \mathrm{mg} / \mathrm{L}$ for well 1, 2, 3, 4, 5 and 6 respectively as shown in table 2 . These values are within NSDWQ and WHO limit of $50 \mathrm{mg} / \mathrm{L}$. The highest value of chloride ion recorded in the samples was $94.08 \mathrm{mg} / \mathrm{L}$ and $18.22 \mathrm{mg} / \mathrm{L}$ as the lowest. The result is similar to that obtained by EPA, [25]. This range is within the NSDWQ and WHO limit of $250 \mathrm{mg} / \mathrm{L}$. Above this limit can readily react with proteins in human hair and can cause health problem.

The phosphate levels of the sample ranged from $1.99 \pm$ $0.02 \mathrm{mg} / \mathrm{L}$ (well 6) $-6.25 \pm 0.08 \mathrm{mg} / \mathrm{L}$ (well 5) and the range is within the NSDWQ and WHO permissible limit of $6.50 \mathrm{mg} / \mathrm{L}$. phosphate level greater than $6.5 \mathrm{mg} / \mathrm{L}$ can lead to kidney damage and osteoporosis as reported by EPA, [25].

The range of nitrate level of the samples is $18.26 \pm$ $0.33 \mathrm{mg} / \mathrm{L}$ (well 3) to $50.80 \pm 0.43 \mathrm{mg} / \mathrm{L}$ (well 4). The value obtained from Well 4 is above the NSDWQ and WHO limit of $50 \mathrm{mg} / \mathrm{L}$. This high level of nitrate may be attributed to the use of fertilizer containing nitrogen and leaching of sewage rich in nitrate as reported by Paul, [26]. Nitrate above $50 \mathrm{mg} / \mathrm{L}$ causes neurological disorder (blue-baby syndrome) in infant less the six months [2].

The nitrite concentration of the samples ranged from $0.03 \pm$ $0.02 \mathrm{mg} / \mathrm{L}$ (well 6) $-0.11 \pm 0.01 \mathrm{mg} / \mathrm{L}$ and the range is within the NSDWQ and WHO permissible limit of $0.20 \mathrm{mg} / \mathrm{L}$. higher level of nitrite has the same effect as in nitrate as reported by Mitchell and Stapp [28]. The value is similar to that of Dhananjay et al. [29].

The sulphate concentration is $64.68 \pm 0.06,89.22 \pm 0.09$, $92.74 \pm 0.0929 .01 \pm 0.09,102.27 \pm 0.41$, and $77.25 \pm$ $0.11 \mathrm{mg} / \mathrm{L}$ for well $1,2,3,4,5$ and 6 respectively The value of well 5 is above the NSDWQ permissible limit of $100 \mathrm{mg} / \mathrm{L}$ but still within the WHO permissible limit of $400 \mathrm{mg} / \mathrm{L}$. the high level may be attributed to improper discharge of waste containing sulphate and drainage of mine [30].

From table 3 iron concentration of the sample was recorded for $0.24 \pm 0.02 \mathrm{mg} / \mathrm{L}$ as the highest and $0.07 \pm 0.00 \mathrm{mg} / \mathrm{L}$ as the lowest. The range is within the NSDWQ and WHO permissible limit of $0.30 \mathrm{mg} / \mathrm{L}$. Iron level greater than $0.3 \mathrm{mg} / \mathrm{L}$ produces a sticky slime typically rusty in colour as reported by Wafaa et al., [31]. These values are in agreement with the work of Dhananjay et al., [29].

The manganese ranged from $0.01 \pm 0.00 \mathrm{mg} / \mathrm{L}$ (well 6 and 1) $-0.21 \pm 0.03 \mathrm{mg} / \mathrm{L}$ (well 3 ). Well 3 is above the NSDWQ and WHO limit of $0.20 \mathrm{mg} / \mathrm{L}$. Manganese above $0.20 \mathrm{mg} / \mathrm{L}$ can cause stiff muscle disease and hypertension in patient older than 40 years as reported by Blaurock, [32].

From table 4, all the samples with the exception of well 5 contain coliforms. The present of coliform is an indication that pathogenic bacteria, viruses and protozoans may be present in the sample [33]. There is no present of E.coli in any of the samples.

\section{Conclusion}

From the result obtained, it will be conclude that all the physical parameters are within the NSDWQ and WHO standard with the exceptions of $\mathrm{pH}$ in well 1,2, and 6 which 1s below the standard. Also, all the ions, mineral and metal parameters are suitable for drinking with the exceptions of calcium hardness, nitrate in (well 4) and manganese (in well 3) respectively. All the samples contain coliform with the exception of well 5 but there is no present of E.coli in any of the sample.

\section{References}

[1] J. Yisa, O. T. Jimoh and O. M. Oyibo. Underground water assessment using water quality index.Leonardo Journal of Sciences. 2010, 21, 33-42.

[2] C. R. Ramakrisshniah, C. Sedashiviah and G. Rangama. Assessment of water qualityindex for the groundwater in Tunkur Takul, Karnatuka State, India. Journal of Environmental Protection, 2009, 6, 2, 523-530. 
[3] N. K. Goel. Assessment of Groundwater Pollution on the Bank of River, New Delhi. Indian journal of Water Chem. 2000, 4, 2, 431-436.

[4] C. Nancy. Nancy Research Laboratory, National Marine Sanctuary. "Water Quality.”Austrilia, 2009, 2 I21.

[5] M. J. Ambrose, S. A. Johnson, P. Lamp and R. Jing. Ecological meanings of Environmental terms. Journal of environmental quality. 2007, 5, 3, 29-33.

[6] MDG Report. United Nation Millennium Development Goals Report 2008 "The slum condition with the associated problems of inadequate water and sanitation facilities. ageri, Australia. $2008,126$.

[7] M. O. Dawodu and A. Ipaiyeda. Evaluation of groundwater and stream quality characteristics in the vicinity of a battery factory in Ibadan. Journal of Applied Sciences. 2007, 2, 1071-1076.

[8] P. D. Tyagi, R. Buddhi, K. C. Chauddhary and R. L. Sawhney. Degradation of groundwater quality in industrial area in India. Ind. Journal of Environmental Protection, 2002, 20, 174-181.

[9] UNESCO. (2nd Edition, 1992). United Nations Education, scientific and cultural Organization. Water Quality AssessmentA Guide to use of Biota, Sediment and Water in Environmental Monitoring. Cambridge 243-236, Chapman and Hall publisher.

[10] A. A. Osunkiyesi. Physicochemical Analisis of Ogun River Whithin two locations (Akin-Olugbade and Lafenwa) in Abiokuta, Ogun State, Nigeria. IOSR Journal of Applied sciences, 2012, 1, 4, 24-27.

[11] R. K. Trivedy and P. K. Goel. Chemical and Biological methods for water pollution studies, Environmental publications, Karad, Maharashtra.

[12] S. Hudault, J. Guignut, and A. L. Servin. Escherichia Coli Stains Colonizing the Gastrointestinal Track Protect Germ- free Mice against Salmonella typhimurium. Applied Journal of Environmental Microbiology. 2001, 5,1, 463-466.

[13] J. C. Hennike. Analytical Study of Microorganisms present in Rain water in New Hampshire. Botswana Journal of Hydrology. 1994, 5, 102-105.

[14] O. I. Olalekan, O. S. Olafusi, H. A. Quadri and O. A. Bolarinwa. Influence of Human Activities on the Water Quality of Ogun River in Nigeria. Civil and Environmental Research. 2012, 2, 9, 36-48.

[15] M. K. Olatunji, T. A. Kolawole, B. O. Albert and I. O. Anthony. Assessment of Water Quality in Asa River (Nigeria) and its Indigenous Claris gariepinus fish. International journal of Environmental Research and Public Health. 2011, 8, 4332-4352.

[16] Wilkies University. Wilkies University, Wilkes-Barre, Pennsylvania. "centre for Environmental Quality, Engineering and Earth science,. March, 2009.

[17] R. C. Narasinha, S. V. Dorairaju, R. M. Bujagendra and P. Chalapathi. Statistical Analysis of Drinking water Quality and it's Inpact on Human Health in Chanrdra Giri, Near Tirupati, India. International journal of hydrochemistry, 2011, 4, 2 634-635.

[18] A. O. Ajibare. Assessment of Physicochemical Parameters of Ilaje Local Government Area of Ondo State, Nigeria. International Journal of Fisheries and Aquatic studies. 2014, 5, 84-92.
[19] J. Yisa, P. J. Gana, T. O. Jimoh and D Yisa. Underground water quality assessment in Doko community, Niger State, Nigeria. Journal of Emerging trend in Engineering and Sciences, 2012, 3, 2, 363-366.

[20] C. D. Higgins, A. G. Mann, C. C. Tam and L. C. Lodrigues. The association Between Drinking Water Turbidity and Gastrointestinal Illness. Science World Journal. 2007, 7, 2, 159157.

[21] [21]'. S. Anshu, K. Ravi, G. Vikas and A. Gaurav. Water Quality Assessment of Ramganga River at Moradabad by Physicochemical Parameters Analysis. VSRD Technical and Nontechnical Journal. 2011, 2, 3, 119-127.

[22] D. S. Rathose, N. Rai and P. Ashiya. Physico-chemical of Water of Ayad River at Udanpur, Rajasthan, India. International Journal of Innovative Research in Science, Engineering and Technology, 2014, 3 4, 4-8.

[23] P. I. Olasehinde. The Groundwaters of Nigeria: A Solution to Sustainable National Water Needs 17th Inauguaral Lecture, Federal University of Technology, Minna, 2010.

[24] S. Pramisha, D. Amit and S. K. Chattergee. Physico-chemical Analysis of Surface and Groundwater of Abhanpur in Raipur District, Chahisgah, India. international Journal of Innovative Technology and Exploring Engineering. 2 (5); 2278-3075.25. Lenntech University (1998). Environmentally Friendly Water Treatment and Air Pollution System for Industry, Technical University of Delft, Netherland. Annual Conference on water examination. 2013, 18.

[25] EPA. United State Environmental Protection Agency. Drinking Water Standard and Health adversaries/ Recreational Water Quality Criteria. Washington, 222-229. Top Gold publishers Ltd. May, 2012.

[26] D. R. Paul and R. S. Bryan. Nitrates in drinking water. Collage of agriculture U.S. department of Agriculture and pennsyvania cooperative, U And P Publisher, 2008, 203.

[27] NSDWQ. Nigerian Standard for Drinking Water Quality. Nigerian Industrial Standard, NIS: 2007, 554 1-14.

[28] M. K. Mitchell and W. B. Stapp. (12th edition, 1994). Field manual for water monitoring: an environmental education program for school.

[29] K. Dhananjay, V. Anjal, D. Namita, and M. Nandkishor. Water Quality Assessment of River Gomti in Lucknow. Universal Journal of Environmental Research and Technology. 2013, 3 (3); 337-344.

[30] C. E. Hatch. Quantifying Surface water-groundwater interactions in mississippi. Australian Journal of Applied Science. 1998, 6, 554-557.

[31] S. M. Wafaa, A. Mourad and P. Conerlis. Control of Iron Metabolism in Bacteria in Banchi, Lucia. Electronic book, ISBN 9789400755604, 2013.

[32] E. Blaurock. The Clinical Effects on Manganese. Journal of Biomedical Research, 2001, 13, 231-232.

[33] ODEQ. Oregon Department of Environmental Quality. Direction for Designation of beneficial uses and the limit of pollutants in surface water, Roque River Basin. 1987, 574. 